\title{
Carbonate budget mass estimates for Neogene discoasters from the Equatorial Atlantic (Ceara Rise: ODP Site 927)
}

\author{
INGA PREISS-DAIMLER* KARL-HEINZ BAUMANN \& RÜDIGER HENRICH \\ Faculty of Geosciences, FB 5, University of Bremen, PO Box 330440, 28334 Bremen, Germany \\ *Corresponding author (e-mail: ipd@uni-bremen.de)
}

\begin{abstract}
Mass estimates for Late Miocene and Pliocene (8.6-3.25 Ma) Discoaster species and Sphenolithus are determined using samples of the equatorial Atlantic (Ceara Rise: ODP Site 927). Based on morphometric measurements, 3D computer models were created for 11 Discoaster species and their volumes calculated. From these, shape factors $\left(\mathrm{k}_{\mathrm{s}}\right)$ were derived to allow calculation of mass for differentsized discoasters and Sphenolithus abies. The mass estimates were then used to calculate the contribution of nannofossils to the total nannofossil carbonate. The discoaster contribution ranges from $10 \%$ to $40 \%$, with a decreasing trend through the investigated interval. However, our estimates of total nannofossil carbonate from size-corrected abundance data are consistently $30-50 \%$ lower than estimates from grainsize measurement; this suggests that data based on mass estimates need to be interpreted with caution. J. Micropalaeontol. 31(2): 169-178, July 2012.
\end{abstract}

KEYWORDS: Discoaster, Sphenolithus, carbonate budget, Neogene, Atlantic, shape factors

\section{INTRODUCTION}

Since their evolution, calcareous plankton have significantly altered the carbonate cycle and so played an important part in marine biogeochemistry. The quantification of the relative contributions of different fossil groups to this is desirable, in order to understand past and thus future feedback mechanisms. Here we focus on mass estimates of some of the smallest calcareous plankton, the nannofossils. This is not easy to do since nannofossils are too small to weigh directly. Instead estimates of nannofossil mass have been established for some species and groups of nannofossils from morphometric measurements. The first approach used to estimate coccolith mass was to measure the surface area and multiply by a value of thickness and density of a coccolith (Honjo, 1976; Samtleben \& Bickert, 1990; Knappertsbusch \& Brummer, 1995; Beaufort \& Heussner, 1999). Subsequently, a more sophisticated volume of rotation approach was applied by Young \& Ziveri (2000) for coccoliths with rotational symmetry. These mass estimates were applied to sediment trap data and sediment cores to convert count data to carbonate flux estimates. To date there has been no work on producing mass estimates for Neogene species and, whilst the masses of most Neogene coccoliths can be estimated using data from extant species, there are also several important extinct nannolith groups. This work is intended to fill the gap by presenting an approach for discoasters and sphenoliths, which contribute significantly to pelagic Neogene sediments and so to carbonate budgets.

Discoasters have a striking appearance under the microscope and are invaluable for biostratigraphy. They show similar abundance, size and distribution patterns to coccoliths, so it is reasonable to assume that they formed the cell cover of marine nannoplankton, and probably of Haptophyte algae. Specimens of Discoaster occur in the sedimentary record from the Late Paleocene (c. $60 \mathrm{Ma}$ ) and became extinct at the end of the Pliocene (Bukry, 1971). It has been noted that there is a secular trend in Discoaster morphology, with progressive evolution from massive skeletal elements to more delicate forms, and a parallel reduction in ray number (Bramlette \& Riedel, 1954; Bukry, 1971). Discoasters are also relatively dissolution resistant and so have been used as a dissolution proxy (Ramsay, 1972; Flores et al., 1995; Gibbs et al., 2004). The ecology of Discoaster has traditionally been attributed mostly to warm oligotrophic low latitude surface waters (Haq \& Lohmann, 1976), supported by geochemical evidence (Minoletti et al., 2001).

This work presents twelve 3D models of Discoaster and Sphenolithus based on morphometric measurements on scanning electron microscope (SEM) images from sediments of the Ceara Rise, western equatorial Atlantic, ODP Site 927. The goal of the modelling is to relate a linear dimension (ray length, $r_{1}$ ) to a volume, which can then be transferred to mass. The volume $(V)$ will be represented by the cube of this measure and a shape factor $k_{\mathrm{s}}$ :

$$
V=k_{\mathrm{s}} \times r_{1}^{3} .
$$

This approach of calculating size-independent shape factors $\left(k_{\mathrm{s}}\right)$ for different species has been used previously for determination of the mass of coccoliths with rotational symmetry (Young \& Ziveri, 2000). Since the discoaster shape cannot be obtained through a rotating constant cross-section a 3D modelling approach was applied. In combination with size corrections, shape factors were used to estimate the mass of discoasters through a time slice from 8.6 to 3.25 Ma. The interval includes the major Pliocene coccolith turnover during which significant changes in the morphologic strategy of coccoliths appear to have occurred (Aubry, 2007), which is regarded as a precursor of the subsequent Pleistocene morphologic strategy in nannofossil lineages favouring small sizes and leading to the successive disappearance of Discoaster at the end of the Pliocene.

\section{METHODS AND MATERIAL}

Thirteen samples from ODP Site 927 from the Ceara Rise were taken through an interval from 8.60 Ma to $3.25 \mathrm{Ma}$ (age 


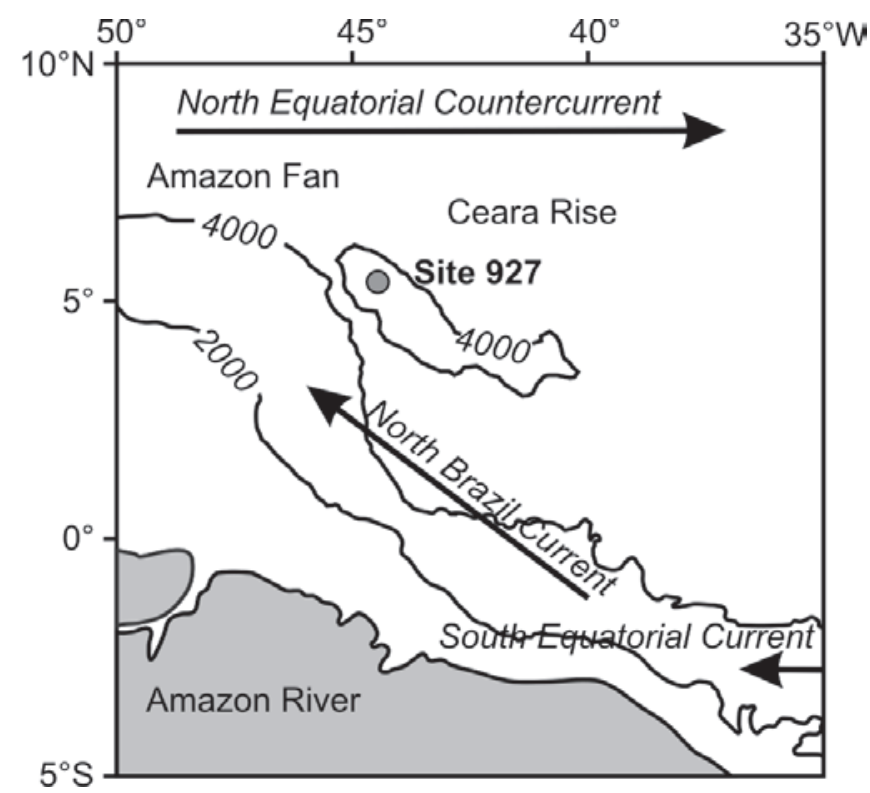

Fig. 1. Location of the study area, ODP Site 927 in the Western Equatorial Atlantic at the southwestern edge of the South Atlantic gyre.

model after Shackleton \& Crowhurst, 1997). The Ceara Rise is an aseismic ridge located $700 \mathrm{~km}$ to the north-east of the mouth of the Amazon River, below the oligotrophic subtropical South Atlantic gyre (Fig. 1). Its sediments are composed of terrigenous clay supplied by fluvial discharge and carbonates from nannofossils and foraminifera. ODP Site 927 sediments are composed of $70-80 \%$ carbonate. Site 927 is located at $3300 \mathrm{~m}$ water depth, well above the lysocline. Bulk sediments were split, with one portion for carbonate measurements and SEM sample preparation, whilst the other portion was wet-sieved at $63 \mu \mathrm{m}$. Bulk samples were analysed for total carbon (TC) and, after removal of carbonate, for total organic carbon (TOC) using a LECO infrared combustion analyser. Carbonate contents were calculated after:

$$
\mathrm{CaCO}_{3}[\mathrm{wt} \%]=(\mathrm{TC}[\mathrm{wt} \%]-\mathrm{TOC}[\mathrm{wt} \%]) \times 8.33 .
$$

\section{SEM preparation and image analysis}

For SEM analysis, approximately $70 \mathrm{mg}$ of bulk sediment were disaggregated in Ammonia buffered water and treated for $3 \mathrm{~s}$ in an ultrasonic bath. The samples were then sub-sampled using a wet splitter and final splits were filtered on to polycarbonate membranes (pore size $0.45 \mu \mathrm{m}$, diameter $47 \mathrm{~mm}$; for method details see Andruleit, 1996). By macroscopic examination, filters with obvious contribution of foraminifera were excluded and preparation was repeated. Filters were then dried, and $0.5 \mathrm{~cm}$ squares were cut out, fixed to SEM stubs and given a gold-palladium coating. Morphometric data were taken from a mixture of all 13 Ceara Rise (denoted 'CRmix') bulk samples. Images were taken at magnifications from $\times 1000$ to $\times 5000$. For the morphometric measurements, the modelling and the calculation of 3D-geometric parameters, a suite of open source software was applied. For image analysis and morphometric measurements ImageJ (http://rsbweb.nih.gov/ij/) was used. Three-dimensional modelling and editing was carried out with Blender (www. blender.org/) and, for model simplification and geometric calculations, Meshlab was used (http://meshlab.sourceforge.net/).

\section{Morphometry of Discoaster and Sphenolithus from SEM images}

Image analysis was carried out on size-calibrated SEM images. The following parameters (Fig. 2) were measured on each ray: Ray length $\left(r_{1}\right)$, area $(A)$, central area width $\left(r_{3}\right)$, half ray width $\left(d_{1}\right)$ and, if present, also the base of the ray tip extension $\left(r_{2}-D\right.$. hamatus, D. surculus, D. variabilis, D. calcaris, D. pentaradia$t u s)$. The base of the ray tip extension was defined differently for D. hamatus and D. calcaris (see Fig. 2a) compared to the other a)

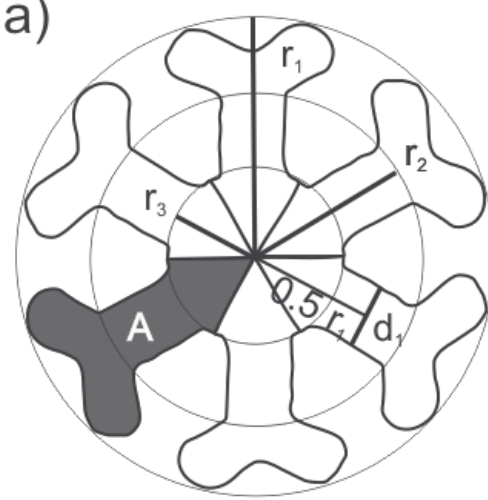

$\mathrm{r}_{2}-$ D. hamatus,

D. calcaris

b)
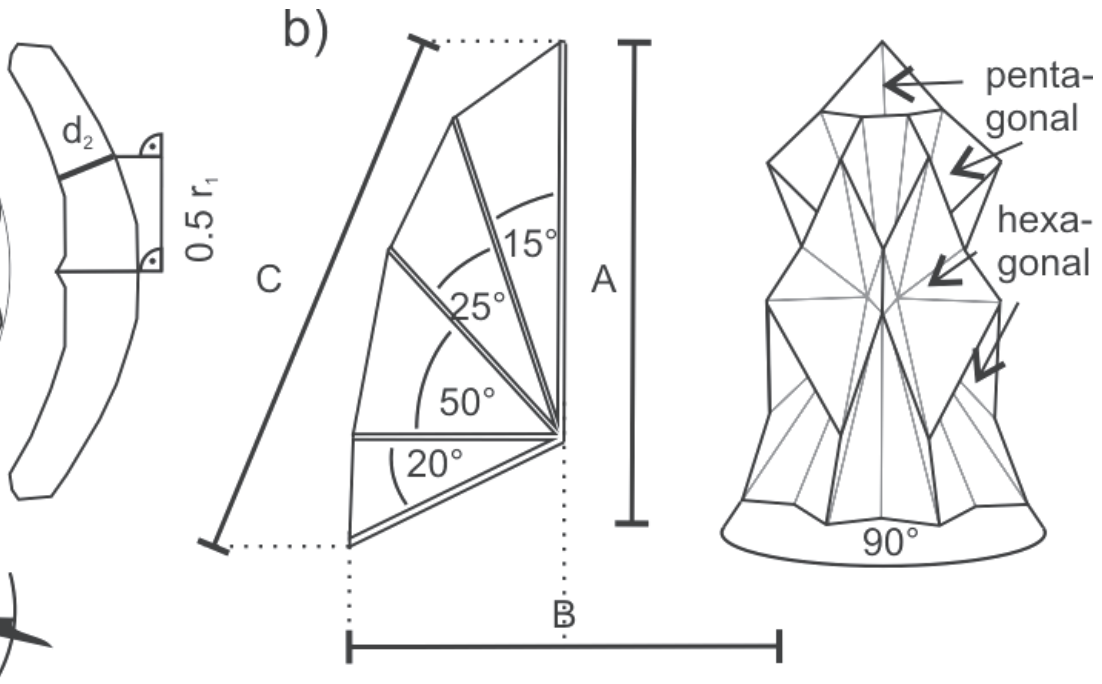

Fig. 2. Parameters measured on each ray in plan view and cross-sectional view. (a) Discoasters $-r_{1}$, ray length; $A$, area; $r_{2}$, ray tip base; $r_{3}$, central area radius; $d_{1}$, half ray width; $d_{2}$ half ray thickness. Note definition of the ray tip base in D. hamatus and D. calcaris. (b) Parameters of Sphenolithus abies model - $A$, height; $B$, width; $C$, maximum diameter. The model has four cycles of triplet blades. 


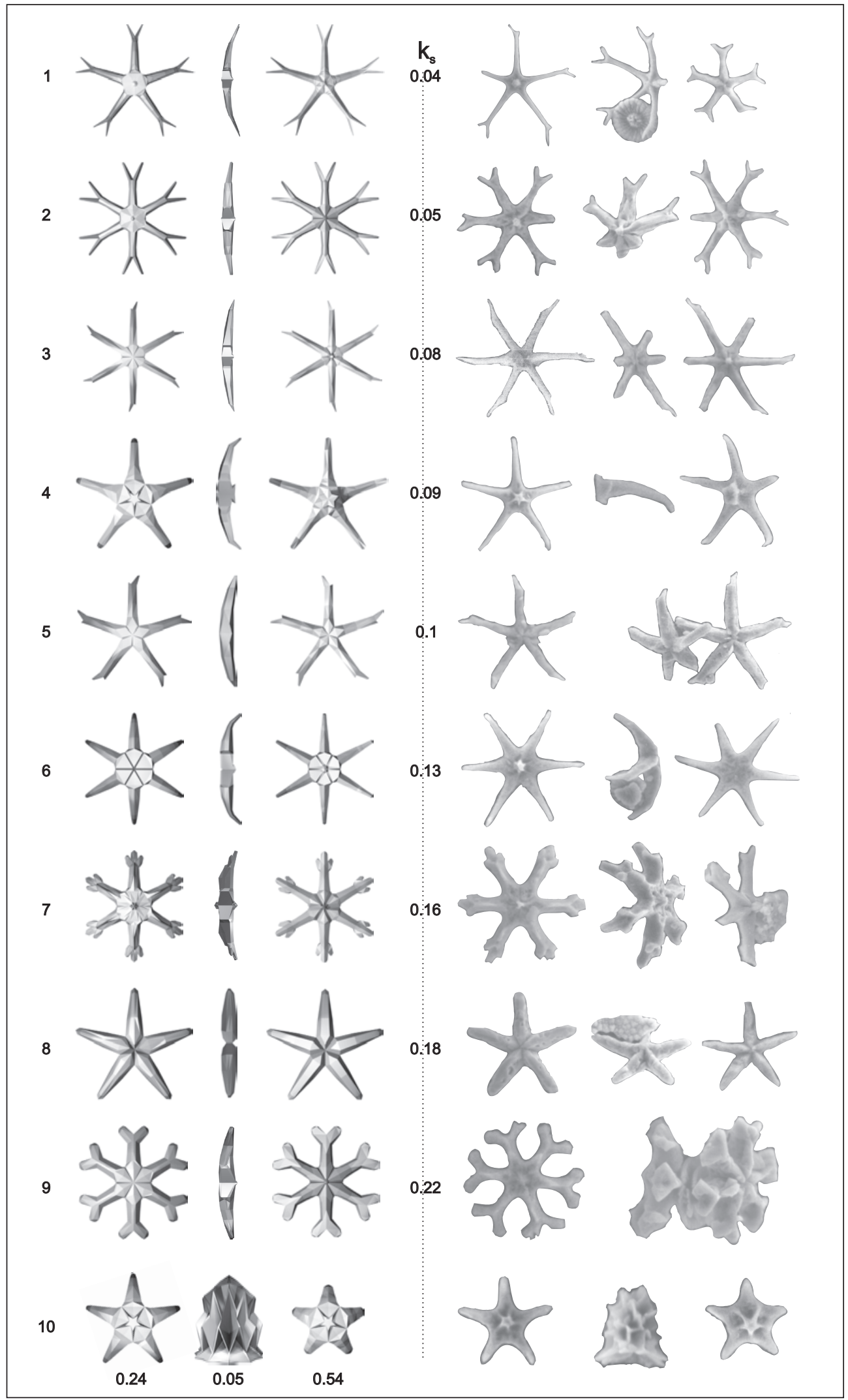

Explanation of Plate 1. Models (left) and SEM pictures of Discoaster groups (right) with increasing $k_{\mathrm{s}}: 1$. D. pentaradiatus; 2. D. exilis; 3. D. calcaris; 4. D. quinqueramus; 5. D. hamatus; 6. D. brouweri; 7. D. surculus; 8. D. bellus; 9. D. variabilis; 10. D. berggrenii, Sphenolithus abies, Discoaster bergenii. 
species. The ray thickness $\left(d_{2}\right)$ could be determined in some cross-sectional debris of single rays or in upright positioned specimens; the thickness was then measured at half of the ray length. Area calculations were based on thresholded images delineating the borders of the particle outline. Some low contrast SEM images did not respond well to thresholding and for these images the outline was drawn manually.

Sphenolithus nannoliths are formed of calcareous blades with a Y-shaped cross-section, radiating from a common origin. The height $(H)$ /length $(L)$ of Sphenolithus and the width of the base $(W)$ were measured. The total number of elements was estimated to be on average 40 . The model consists of 12 elements forming a concave base followed by a second and a third cycle of 12 elements. The last cycle is formed by four elements. Within the first two cycles the elements build hexagonal honeycomb-like forms while, in the third and fourth cycle, the structure is pentagonal (angles between adjacent cycles are shown in Fig. 2b). Apical spines were not observed and so were not included in the model.

The following models (see Plate 1) are based on one or more species:

1. Discoaster variabilis: 6-rayed D. variabilis, contains also D. challengeri, D. loeblichi and more massive forms like $D$. deflandrei. Bifurcation of ray tips is always evident and distal and proximal bosses are common but weak; large bosses typical of $D$. bollii or $D$. petaliformis were very rarely observed. Some specimens of this group are similar to D. surculus; however, they have bifurcate ray tips while $D$. surculus shows three ray tip extensions.

2. Discoaster bellus: 5-rayed discoasters with straight rays and almost undifferentiated central area.

3. Discoaster brouweri: 6-rayed discoasters with flat central area, deflected rays and a distal knob, also $D$. braruudii.

4. Discoaster pentaradiatus: 5-rayed D. prepentaradiatus and more delicate $D$. pentaradiatus showing V-shaped bifurcations.

5. Discoaster quinqueramus-group: 5-rayed discoaster with deflected rays, distal and proximal knobs

6. Discoaster bergenii: as D. quinqueramus but rays with 0.8 times width of the central area.

7. Discoaster berggrenii: as D. quinqueramus but rays with 1.5 times width of the central area.

8. Discoaster surculus: heavily calcified 6-rayed discoaster with deflected rays, distal ridges and distal and proximal knobs.

9. Discoaster hamatus: 5-rayed discoaster with almost straight rays, asymmetric ray-tips are deflected, no knobs.

10. Discoaster calcaris: 6-rayed discoaster otherwise similar to D. hamatus.

11. Discoaster exilis: 6- rayed discoaster with straight rays, bifurcations on ray tips and weak distal knob.

12. Sphenolithus: predominantly S. abies with cuspate outlines and as described above.

Obtaining statistical relationships from distal, proximal and cross-sectional views of specimens

Of all the measurable parameters of planar nannofossils, area $(A)$ should represent the closest relationship to the volume, so linear regression was used to investigate the dependence of all other, linear, parameters on area (see Fig. 2) (except thickness $-d_{2}-$ see below) assuming that the underlying relationship generally is:

$$
A=k_{\mathrm{a}} \times(\text { parameter })^{2},
$$

with $k_{\mathrm{a}}$ being a constant shape factor for each parameter. The factor $k_{\mathrm{a}}$ is a first hint of the degree of calcification. Increasing $k_{\mathrm{a}}$ points to heavy calcification independent of size. The calculated $k$-values and coefficients of determination are reported in Table 1.

Having established the correlation between the surface and surface-parallel measurements, the third dimension was added to the model. Unfortunately, it is not possible to measure the thickness, the area and the other parameters on the same specimen from SEM pictures. Thus, for cross-sectional views broken rays or vertically orientated discoasters were measured. These images gave thickness $\left(d_{2}\right)$ and ray length $\left(r_{1}\right)$ for which the underlying relationship is supposed to be:

$$
r_{1}=d_{2} \times c
$$

with $c$ being a constant between 0 and 1. Estimates for this relationship are reported in Table 2.

\section{From morphometric measures to model}

To synthesize the morphometric data into a $3 \mathrm{D}$ model we chose the area for the model as being the mean of the surfaces measured. From this mean area subsequently all other parameters $\left(r_{1}, r_{2}, r_{3}, d_{1}, d_{2}\right)$ were calculated for the model measurements according to the correlations given in Tables 1 and 2. Models were constructed as polygonal objects in Blender (see Plate 1). The model volumes were calculated with Meshlab using the in-built algorithm, which is based on the finite element method. The length of one ray was then related to volume, thus it is represented by the cube of the length $\left(r_{1}\right)$ and a shape factor $k_{\mathrm{s}}$ (equation 1).

\section{Sedigraph analysis}

In order to evaluate the mass estimates, further grain-size measurements were made. Grain-size measurements on the silt fraction $(2-63 \mu \mathrm{m})$ of six samples were carried out using a Sedigraph 5100 particle size analyser following the procedure of Frenz et al. (2005) after removal of clay $(<2 \mu \mathrm{m})$ through repeated settling (up to 30 times) in Atterberg tubes. The Sedigraph assigns settling diameters (equivalent spherical diameter - ESD) to the grains.

The calcareous silt fraction of open ocean pelagic sediments often shows an almost bimodal distribution (Fig. 3), in which the coarser part is constituted of foraminifera and their fragments divided by a minimum from coccoliths and other nannoliths in the fine silt and clay fraction (McCave et al., 1995; Frenz et al., 2005). The position of this minimum varies from about $8-10 \mu \mathrm{m}$ (see Fig. 3) depending on the technique and sample.

According to our results (Preiß-Daimler, unpublished $\mathrm{PhD}$ thesis, University of Bremen, 2011) and Frenz et al. (2006), the non-carbonate fraction is predominantly terrigenous, owing to the absence of opal. Furthermore, it is predominantly enriched in the fine silt and clay fractions. In Pliocene samples of Site 927 
Table 1. Statistical relationships in discoaster specimens of 'CR-mix' sample.

\begin{tabular}{|c|c|c|c|c|c|c|c|c|c|}
\hline 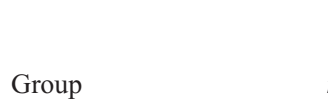 & $n$ & \multicolumn{2}{|c|}{$r_{1}-A$} & \multicolumn{2}{|c|}{$d_{1}-A$} & \multicolumn{2}{|c|}{$r_{2}-A$} & \multicolumn{2}{|c|}{$r_{3}-A$} \\
\hline D. bellus & 51 & 0.19 & 0.93 & 3.27 & 0.25 & & & 3.16 & 0.70 \\
\hline D. brouweri & 54 & 0.14 & 0.71 & 4.76 & 0.10 & & & 1.62 & 0.44 \\
\hline D. calcaris & 48 & 0.11 & 0.57 & 7.33 & -1.51 & 0.15 & -0.36 & 2.83 & 0.29 \\
\hline D. exilis & 32 & 0.13 & 0.79 & 8.60 & -0.07 & 0.27 & 0.57 & 2.61 & 0.57 \\
\hline D. quinqueramus & 47 & 0.13 & 0.62 & 7.71 & 0.20 & & & 2.28 & 0.66 \\
\hline D. surculus & 50 & 0.18 & 0.68 & 5.79 & -0.54 & 0.41 & -0.17 & 2.27 & 0.28 \\
\hline D. variabilis & 44 & 0.26 & 0.80 & 5.06 & 0.08 & 0.56 & 0.44 & 2.84 & 0.14 \\
\hline
\end{tabular}

Table 2. Relationships of discoaster thickness and ray length.

\begin{tabular}{lrc}
\hline Group & $n$ & $r_{1}-d_{2}$ \\
\hline D. bellus & 9 & 0.266 \\
D. brouweri & 11 & 0.199 \\
D. calcaris & 4 & 0.149 \\
D. exilis & 7 & 0.161 \\
D. hamatus & 6 & 0.182 \\
D. pentaradiatus & 12 & 0.104 \\
D. quinqueramus & 6 & 0.168 \\
D. surculus & 14 & 0.257 \\
D. variabilis & 30 & 0.235 \\
\hline
\end{tabular}

proportions of terrigenous silt comprise $0.8-2 \%$ in the coarse silt $(10-63 \mu \mathrm{m})$, with a tendency to lower values in the Miocene. For simplicity we, therefore, allocate the terrigenous fraction to the fine silt $(<8 \mu \mathrm{m}$ ESD) and clay fraction $(<2 \mu \mathrm{m}$ ESD). According to this the nannofossil carbonate fraction $<63 \mu \mathrm{m}$ is:

Nannofossil carbonate $(\mathrm{wt} \%)=\frac{\left[\begin{array}{c}\text { fine fraction }<63 \mu \mathrm{m}(\mathrm{g})- \\ \text { coarse silt }(\mathrm{g})-\text { terrigenous fraction }(\mathrm{g})\end{array}\right]}{\text { fine fraction }(\mathrm{g})} \times 100$.

\section{RESULTS}

\section{Assemblage counts and estimation of Ceara Rise Site} 927 nannofossil mass distribution

In the following we applied our $k_{\mathrm{s}}$ estimates and $k_{\mathrm{s}}$ values from the literature (Beaufort \& Heussner, 1999; Young \& Ziveri, 2000; Table 3) to calculate the relative contributions of different species to carbonate flux from assemblage counts on 13 samples of Ceara Rise Site 927. In order to reduce errors, size corrections were introduced. During assemblage counting size assignments had already been made for Reticulofenestra (Table 3) and Calcidiscus leptoporus; for further size correction about 30 specimens were measured using placolith diameter, spine length, sphenolithus length or discoaster ray length. This mean size was calculated as a mean volume following the suggestion of Young \& Ziveri (2000), in order to avoid under-estimation due to deviations from normally distributed sizes.

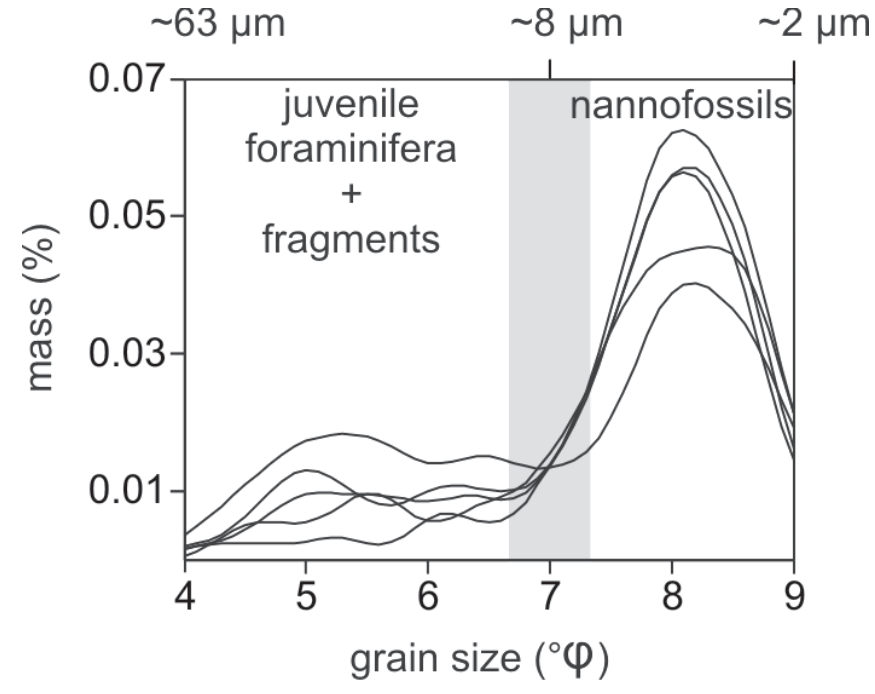

Fig. 3. Sedigraph measurements of silt distributions of six samples, showing characteristic polymodal distributions, which can roughly be divided into nannofossils and foraminifera and fragments at about $8 \mu \mathrm{m}$.

Throughout the record the smallest specimens are numerically dominant, such as Reticulofenestra spp., Florisphaera profunda and Umbilicosphaera spp.. However, the lower half of the record contains up to $15 \%$ discoasters (see Fig. $4 \mathrm{a}$ ). The calculated nannofossil content comprises about $10-30 \%$ of the total sediment and this can probably be regarded as a minimum value (see Discussion). The discoasters' contribution to the mass is 11-42 $\mathrm{wt} \%$ of the total nannofossil carbonate and accounts for 2-11 wt $\%$ of the total sediment (Fig. 4b). Discoasters show a decreasing trend over the interval in both abundance and mass. Together with Discoaster, Reticulofenestra, Helicosphaera and Calcidiscus form $70-80 \%$ of the total nannofossil carbonate. Most mass within discoaster carbonate is contributed by the D. variabilis, $D$. brouweri, D. quinqueramus, D. pentaradiatus and D. surculus specimens (Fig. 4c).

\section{Granulometric estimate of nannofossil carbonate}

The silt distribution offers a method to discriminate foraminiferal carbonate from nannofossil carbonate and so allowed an estimation 
Table 3. Parameter measured, mean length, $k_{\mathrm{s}}$ values applied in this study and from literature (either Young \& Ziveri, $2000^{1}$ or Beaufort \& Heussner, $\left.1999^{2}\right)$ and size-corrected masses.

\begin{tabular}{|c|c|c|c|c|c|c|c|}
\hline Species & $\begin{array}{l}\text { Parameter } \\
\text { measured }\end{array}$ & $\begin{array}{l}\text { Mean size } \\
\quad(\mu \mathrm{m})\end{array}$ & $k_{\mathrm{s}}$ & range (pg) & mean (pg) & $\begin{array}{l}\text { Mean mass } \\
\left(k_{\mathrm{s}} \text { source }\right) \\
\quad(\mathrm{pg})\end{array}$ & Source of $k_{\mathrm{s}}$ \\
\hline D. exilis & Ray length & 7.7 & 0.05 & $7-21$ & 16.5 & - & This study \\
\hline D. calcaris & Ray length & 6.5 & 0.08 & $34-155$ & 80.7 & - & This study \\
\hline D. quinqueramus & Ray length & 6.9 & 0.09 & $4-363$ & 44 & - & This study \\
\hline D. brouweri & Ray length & 5.9 & 0.13 & $7-343$ & 58 & - & This study \\
\hline D. surculus & Ray length & 8.4 & 0.16 & $55-562$ & 219.5 & - & This study \\
\hline D. bellus & Ray length & 6.2 & 0.18 & $57-178$ & 116.5 & - & This study \\
\hline D. variabilis & Ray length & 5.7 & 0.22 & $20-548$ & 113.1 & - & This study \\
\hline D. berggrenii & Ray length & 6.9 & 0.24 & $32-94$ & 55 & - & This study \\
\hline D. bergenii & Ray length & 6.2 & 0.54 & $18-46$ & 33.4 & - & This study \\
\hline Coccolithus pelagicus & Length & 9.8 & 0.06 & $86-210$ & 67 & 99.5 & 1 \\
\hline Gephyrocapsa sp. (small) & Length & 2.4 & 0.05 & $0.2-5$ & 1.1 & & Estimate - this study \\
\hline Reticulofenestra minuta (open $<3 \mu \mathrm{m}$ ) & Length & 2.7 & 0.05 & $0.4-4$ & 2.1 & - & Estimate - this study \\
\hline R. minutula/haquii (open $3-5 \mu \mathrm{m}$ ) & Length & 4 & 0.05 & $4-17$ & 7.4 & - & Estimate - this study \\
\hline R. productella $($ closed $<4.5 \mu \mathrm{m})$ & Length & 4 & 0.05 & - & 8.64 & - & Estimate - this study \\
\hline$R$. perplexa $($ closed $>4.5 \mu \mathrm{m})$ & Length & 5 & 0.06 & - & 20.3 & - & Estimate - this study \\
\hline R. pseudoumbilicus (open 5-7 $\mu \mathrm{m}$ ) & Length & 6 & 0.06 & $20-65$ & 32.62 & - & Estimate - this study \\
\hline Florisphaera profunda & Length & 2.6 & 0.03 & $0.3-6$ & 1.82 & 1.3 & 1 \\
\hline Helicosphaera carteri & Length & 10.5 & 0.06 & $83-353$ & 190.7 & 135.0 & Average between ${ }^{1}$ and ${ }^{2}$ \\
\hline$H$. spp. & Length & 8.8 & 0.06 & $40-131$ & 96.8 & & Like $H$. carteri \\
\hline Pseudoemiliana lacunosa & Length & 4 & 0.04 & $1.8-13$ & 4.8 & & Estimate - this study \\
\hline
\end{tabular}

The mean size of Sphenolithus abies refers to the height.

of the nannofossil carbonate share (equation 5). The results (Table 4) show a consistent discrepancy between these two estimates. The Sedigraph-based estimate of the contribution of the nannofossil fraction to the $<63 \mu \mathrm{m}$ fraction ranges from $24 \%$ to $44 \%$, whilst the assemblage count data suggest nannofossils account for only $15-22 \%$.

\section{DISCUSSION}

First, considerations regarding errors in the group concept are described, and possible errors in the basic data of the modelling approach are discussed. However, it should be stressed here that the main uncertainty in mass estimates is related to the size variation. Afterwards the nannofossil carbonate budgets are evaluated with respect to grain-size-based budget estimates. And, finally, the results of the application of $k_{\mathrm{s}}$-values to Ceara Rise Site 927 sediments and possible implications are discussed.
Error sources in modelling concept and in model setup

A key assumption in the volume and mass estimates is that the form is scale invariant (Young \& Ziveri, 2000) or at least that size-dependent shape-change causes trivial differences in volume. However, our mixed sample includes about 6 million years of Discoaster evolution, during which time the group underwent changes in genotypes and phenotypic expression and, indeed, some of the morphometric groups contain more than one species. Thus, some of the observed data variance can probably be assigned to the group concept, allowing for some differences in the morphology. An example for this is given by the $D$. pentaradiatus group which contains specimens of $D$. prepentaradiatus which is rather robust and the typically delicate $D$. pentaradiatus (see Plate 1 - right side of first row). Here our group-based $k_{\mathrm{s}}$ estimate underrates the smaller but more massive shape of $D$. prepentaradiatus and overrates $D$. pentaradiatus values (see Plate 1). 
Carbonate budget mass estimates for Neogene discoasters

(a)

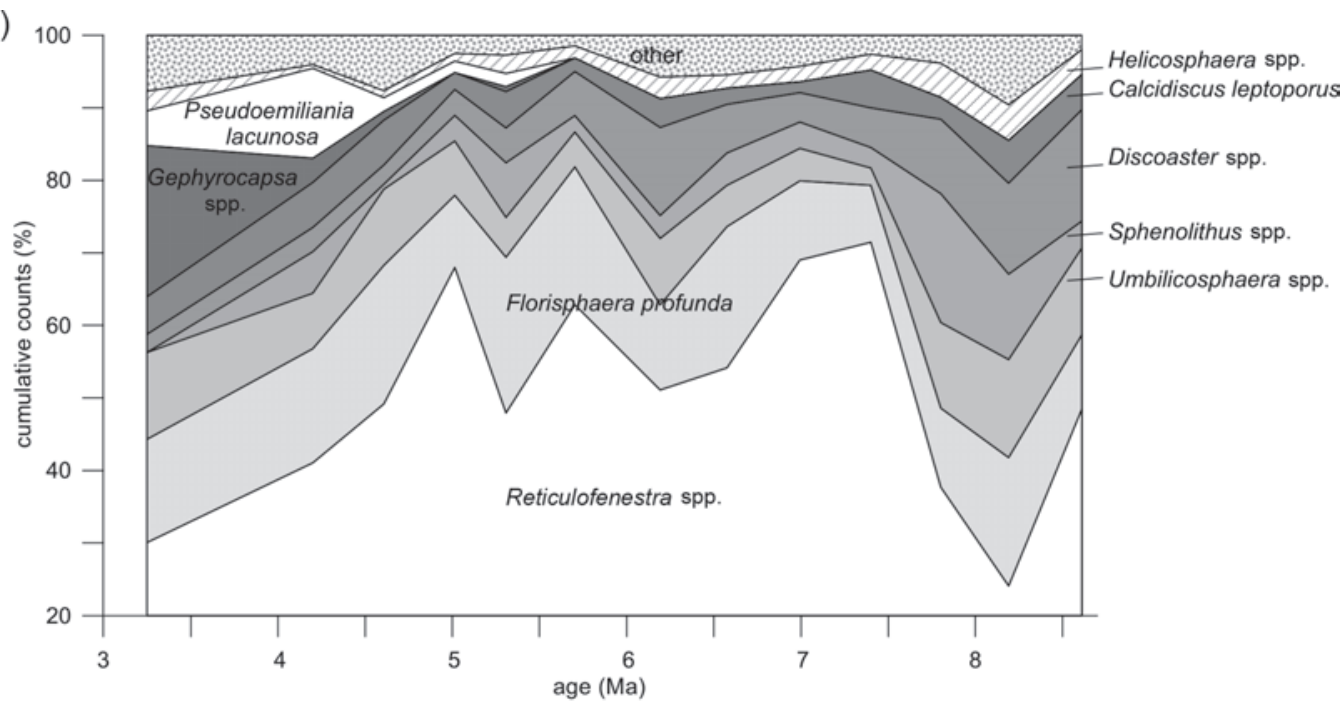

(b)
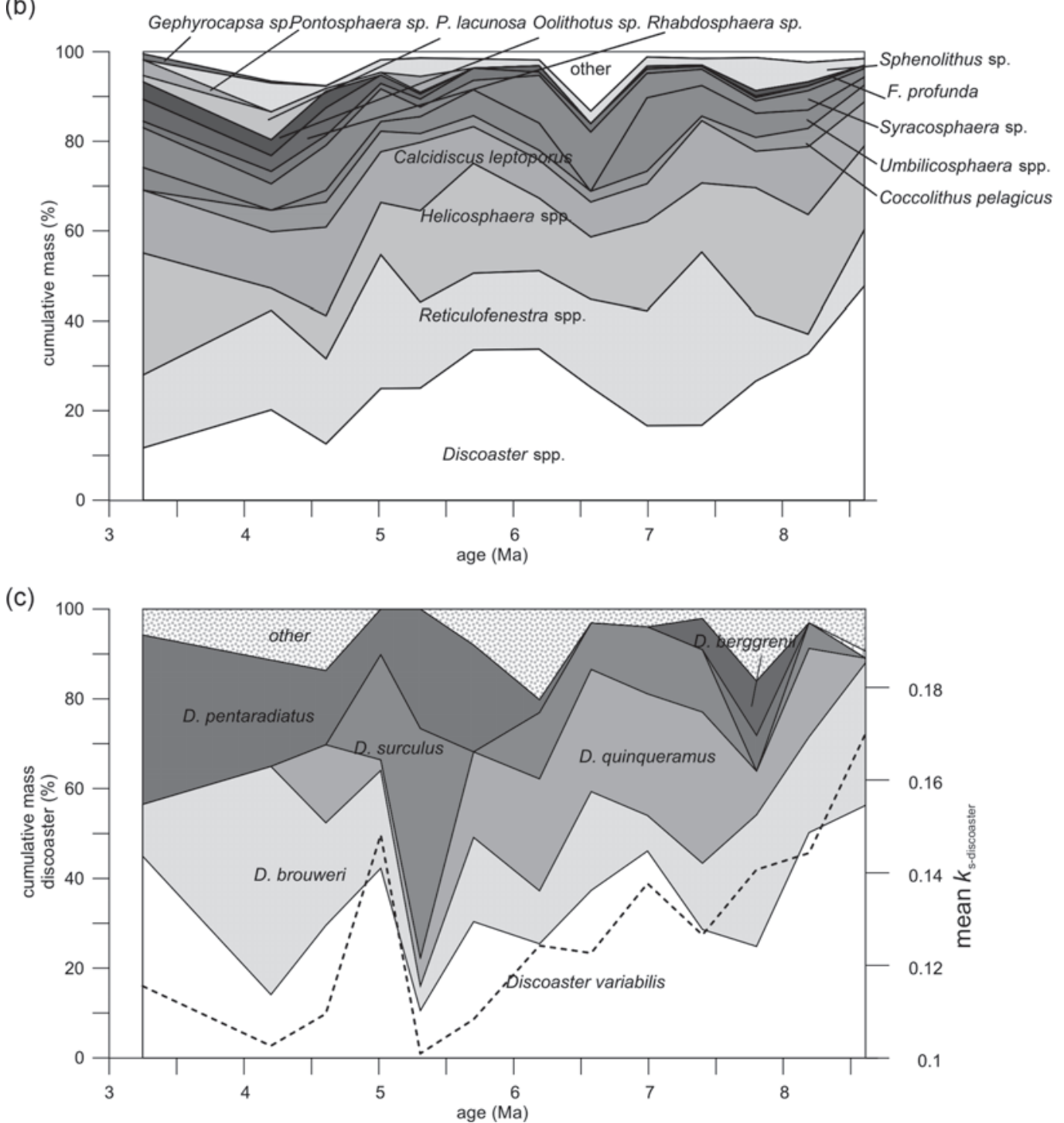

Fig. 4. Nannofossil assemblage data of Site 927 from 8.6 Ma to 3.25 Ma. (a) Cumulative counts of nannofossils; (b) cumulative mass of the assemblage; (c) cumulative discoaster mass and mean $k_{\mathrm{s}}$ of Discoaster (dashed line). 
Table 4. Comparison of nannofossil carbonate content by two methods.

\begin{tabular}{lcc}
\hline Sample & $\begin{array}{c}\text { Total nannofossil } \\
\text { carbonate }- \text { SEM method }\end{array}$ & $\begin{array}{c}\text { Total nannofossil } \\
\text { carbonate }-<63 \mu \mathrm{m}\end{array}$ \\
\hline No. $927-$ & $(\mathrm{wt} \%)$ & $(\mathrm{wt} \%)$ \\
C $15-2-125.5 \mathrm{~cm}$ & 14.7 & 24.0 \\
A $19-5-29 \mathrm{~cm}$ & 18.3 & 31.0 \\
B 21-3-32 cm & 15.0 & 33.2 \\
B 22-5-12 cm & 21.5 & 32.8 \\
B 23-5-26 cm & 22.5 & 44.3 \\
C 23-5-93.5 cm & 17.5 & 36.6 \\
\hline
\end{tabular}

Such allometric tendencies have also been shown, for example, within the $D$. quinqueramus group. There is a trend from smaller more heavily calcified forms (D. bergenii and D. berggrenii) toward larger less heavily calcified forms (D. quinqueramus). Obviously overgrown specimens were excluded from our calibration dataset but overgrowth is evident in some samples. Other errors may be induced by minor breakage, dissolution or by slight tilting of specimens. In general the more delicate forms (lower $k_{\mathrm{s}}$ ) would be more prone to these forms of errors.

\section{Underestimation in mass estimates - a comparison to nannofossil carbonate estimate from granulometry}

The splitting of the samples resulted in the distribution of a known mass on the filter representative of the bulk sample. However, even one foraminiferal test can exceed the weight of the fraction used for investigations, thus filters with adult foraminifera tests were excluded (see Methods above). Accordingly, the calcareous fine fraction distributed on the filter is represented by juvenile foraminifera, their fragments and nannofossils from the silt fraction. The nannofossil carbonate share could be corrected for this foraminifera carbonate. Despite these corrections mass estimates involving $k_{\mathrm{s}}$-based estimates are lower than Sedigraph-based estimates. One probable explanation for the

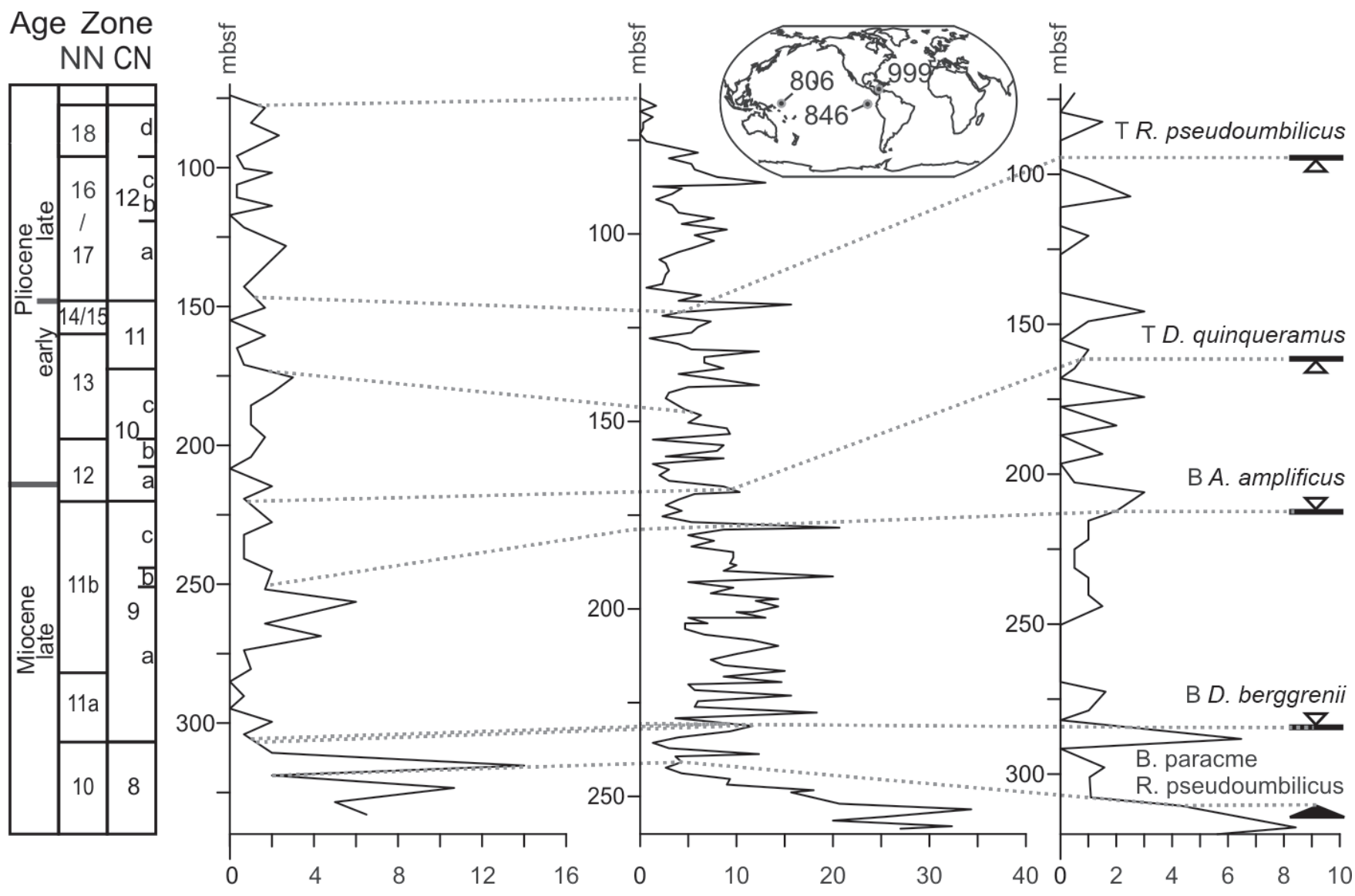

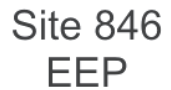

Discoaster spp. \%

\section{Site 999}

\section{Site 806 WEP}

Fig. 5. Abundance data of Discoaster spp. from other low latitude locations. From left to right: ODP Site 846 in the Eastern Equatorial Pacific (data from Kameo \& Sato, 2000; nannofossil datums according to Raffi \& Flores, 1995); ODP Site 999 in the Caribbean (data from Kameo \& Sato, 2000; nannofossil datums according to Kameo \& Bralower, 2000); ODP Site 806 in the WEP (data and position of nannofossil datums from Takayama, 1993). In each core the reductions in the discoaster abundance record are associated with the base of the paracme of R. pseudoumbilicus. 
consistently lower values is given by the occurrence of aggregates and broken nannofossils on the filters, which are not part of the budget estimate (a discoaster that comprises more than half of a test was considered to be part of the budget and double counting was avoided). The presence of overgrowth is evident and probably also contributes to this discrepancy. However, it has been shown from sediment trap data that flux estimates result in underestimations compared to the fraction $<32 \mu \mathrm{m} \mathrm{CaCO}_{3} \mathrm{wt} \%$ even in well-preserved samples (Broerse et al., 2000).

\section{Significance of discoaster carbonate contribution in low latitudes of the late Miocene to Pliocene}

The time interval chosen for the application of new shape factors is part of the gradual Mid-Miocene to Pleistocene cooling. The onset of bipolar glaciation leads to the successive disappearance of discoaster species (from about 3-2 Ma). This progressive disappearance of discoasters provides well-established biostratigraphic events and is accompanied by decreasing ray numbers, and so decreasing degree of calcification, in discoasters. The carbonate budget results show that discoasters contribute significant amounts of nannofossil carbonate, in the order of 10-40\%, despite relative abundance counts as low as $2-15 \%$. Both discoaster abundance and mass estimates show a long-term decrease. A change in shape accompanies this trend, as summarized by progressive decrease in mean $k_{\text {s-discoaster }}$ which was calculated according to the proportion of morphological groups:

$$
\text { mean } k_{\text {s-discoaster }}=\sum k_{\text {s-group }} \times \text { proportion }_{\text {group }} .
$$

The trend (Fig. 3c) is caused by the progressive dominance of more slender nannoliths recorded as increasing abundance of $D$. pentaradiatus and D. brouweri at the expense of $D$. varabilis and D. surculus.

Abundance data from three low latitude sites are compared in Figure 5. This suggests that the decline in abundance of discoasters in the Caribbean (Site 999), the Eastern Equatorial Pacific (EEP - Site 846) and Western Equatorial Pacific (WEP - Site 806) occurred at about the same time as in the record of Ceara Rise, within zone NN10 of the Late Miocene, and associated with the small Reticulofenestra interval (beginning at $8.85 \mathrm{Ma}$ ). The most obvious explanation for this pattern is that dilution through smaller but higher abundance coccoliths caused the rapid decrease in abundance of discoasters (in counts of about 300 particles). Additionally, dissolution might produce this type of downcore pattern. The interval is known to follow the carbonate crash events (12-9 Ma), which are characterized by strong carbonate dissolution in the EEP, the Atlantic and the Caribbean (Lyle et al., 1995; King et al., 1997; Roth et al., 2000). However, Site 806 (WEP - $2530 \mathrm{~m}$ water depth) is situated above the local lysocline and foraminifera are well to moderately preserved (Kroenke et al., 1991; Janecek, 1993). In order to evaluate whether the abundance changes are accompanied by flux changes, counts of specimens per weight and subsequent application of mass calculations as outlined here would be invaluable to constrain the actual causes of this major assemblage shift.

\section{CONCLUSIONS}

1. Shape factors of discoasters as determined from 3D models range from 0.04 up to 0.54 with increasing degree of calcification. For Sphenolithus abies, $k_{\mathrm{s}}$ is calculated to be 0.05 .

2. The size-corrected estimate of carbonate mass from discoaster nannoliths comprises $10-40 \mathrm{wt} \%$ of the total calculated nannofossil carbonate.

3. Both the abundances of discoasters and estimates of their mass contribution decline through the studied interval (8.6-3.25 Ma), associated with a general trend to more slender forms.

4. The nannofossil content estimates from granulometric measurements (Sedigraph) are consistently higher that the nannofossil contents calculated using nannofossil counts and shape factors. The most likely causes of this discrepancy are uncounted aggregates, breakage and overgrowth, all resulting in the count-based calculation being an underestimate. Thus, shape factor-based nannofossil carbonate estimates might be referred to as minimum contents.

\section{ACKNOWLEDGEMENTS}

We are indebted to the open source software developers for their work on the software Blender, MeshLab and ImageJ, contributing the tools for modelling and image analysis. Thoughtful comments of Jeremy Young and two anonymous reviewers greatly improved this manuscript. We also gratefully acknowledge the work of Helga Heilmann and Britt Kockisch, providing the basic laboratory equipment and support. This research used samples provided by the Ocean Drilling Program (ODP). ODP is sponsored by the US National Science Foundation (NSF) and participating countries under management of Joint Oceanographic Institutions (JOI). This study was funded by the Deutsche Forschungsgemeinschaft (DFG-Grant number He 1671/ 15).

\section{Manuscript received 24 May 2011 \\ Manuscript accepted 5 March 2012}

Scientific Editing by Jeremy Young.

\section{APPENDIX A: TAXONOMIC LIST}

Following the descriptions of Perch-Nielsen (1985) and references therein.

Discoaster bellus Bukry \& Percival, 1971

Discoaster bergenii Knuttel, Russell \& Firth, 1989

Discoaster berggrenii Bukry, 1971

Discoaster brouweri Tan, 1927

Discoaster braarudii Bukry, 1971

Discoaster bollii Martini \& Bramlette, 1963

Discoaster calcaris Gartner, 1967

Discoaster challengeri Bramlette \& Riedel, 1954

Discoaster deflandrei Bramlette \& Riedel, 1954

Discoaster hamatus Martini \& Bramlette, 1963

Discoaster loeblichii Bramlette \& Riedel, 1954

Discoaster pentaradiatus Tan, 1927

Discoaster petaliformis Moshkovitz \& Ehrlich, 1980

Discoaster prepentaradiatus Bukry \& Percival, 1971

Discoaster quinqueramus Gartner, 1969

Discoaster surculus Martini \& Bramlette, 1963

Discoaster variabilis Martini \& Bramlette, 1963

Sphenolithus abies Deflandre in Deflandre \& Fert, 1954 


\section{REFERENCES}

Andruleit, H. 1996. A filtration technique for quantitative studies of coccoliths. Micropaleontology, 42: 403-406.

Aubry, M.-P. 2007. A major Pliocene coccolithophore turnover: Change in morphological strategy in the photic zone. In Monechi, S., Coccioni, R. \& Rampino, M.R. (Eds), Large Ecosystem Perturbations: Causes and Consequences. Geological Society of America Special Papers 2007, 424: 25-51.

Beaufort, L. \& Heussner, S. 1999. Coccolithophorids on the continental slope of the Bay of Biscay. Production, transport and contribution to mass fluxes. Deep-Sea Research II, 46: 2147-2174.

Bramlette, M.N. \& Riedel, W.R. 1954. Stratigraphic value of discoasters and some other microfossils related to recent coccolithophores. Journal of Paleontology. 28: 385-403.

Broerse, A., Ziveri, P., Hinte, J.E. van \& Honjo, S. 2000. Coccolithophore export production, species composition and coccolith-CaCO3 fluxes in the NE Atlantic (343N 213Wand 483N 213W) In Ganssen, G.M. \& Wefer, G. (Eds), Particle Flux and its Preservation in Deep Sea Sediments. Deep-Sea Research II, 47: 1877-1905.

Bukry, D. 1971. Discoaster evolutionary trends. Micropaleontology, 17: 43-52.

Flores, J.-A., Sierro, F.J. \& Raffi, I. 1995. Evolution of the calcareous nannofossil assemblage as a response to the paleoceanographic changes in the eastern equatorial Pacific Ocean from 4 to 2 Ma (Leg 138, Sites 849 and 852). In Pisias, N.G., Mayer, L.A., Janecek, T.R., Palmer-Julson, A. \& Andel, T.H. van (Eds), Proceedings of Ocean Drilling Program, Scientific Results, 138: 163-176.

Frenz, M., Baumann, K.-H., Boeckel, B., Hoppner, R. \& Henrich, R. 2005. Quantification of foraminifer and coccolith carbonate in South Atlantic surface sediments by means of carbonate grain-size distributions. Journal of Sedimentary Research, 75: 468-479.

Frenz, M., Henrich, R. \& Zychla, B. 2006. Carbonate preservation patterns at the Ceará Rise - Evidence for the Pliocene super conveyor. Marine Geology, 232: 173-180.

Gibbs, S., Shackleton, N.J. \& Young, J. 2004. Identification of dissolution patterns in nannofossil assemblages: A high resolution comparison of synchronous records from Ceara Rise, ODP Leg 154 Paleoceanography, 19/1029: 1-12.

Haq, B.U. \& Lohmann, G.P. 1976. Early Cenozoic calcareous nannoplankton biogeography of the Atlantic Ocean. Marine Micropaleontology, 1: 119-194.

Honjo, S. 1976. Coccoliths: production, transportation, and sedimentation. Marine Micropaleontology, 1: 65-79.

Janecek, T.R. 1993. Data report: high-resolution carbonate and bulk grain-size data for Sites 803-806 (0-2 Ma). In Berger, W.H., Kroenke, L.W., Mayer, L.A. et al., Proceedings of the Ocean Drilling Program, Scientific Results, 130: 761-773.

Kameo, K. \& Bralower, T.J. 2000. Neogene calcareous nannofossil biostratigraphy of Site 998, 999, and 1000, Caribbean Sea. In Leckie, R.M., Sigurdsson, H., Acton, G.D. \& Draper, G. (Eds), Proceedings of the Ocean Drilling Program, Scientific Results, 165: 3-17.

Kameo, K. \& Sato, T. 2000. Biogeography of Neogene calcareous nannofossils in the Caribbean and the eastern equatorial Pacific-floral response to the emergence of the Isthmus of Panama. Marine Micropaleontology, 39: 201-218.

King, T.A., Ellis, W.G., Murray, D.W., Shackleton, N.J. \& Harris, S. 1997. Miocene evolution of carbonate sedimentation at the Ceará Rise: a multivariate data/proxy approach. Proceedings of the Ocean Drilling Program, Scientific Results, 154: 349-365.

Knappertsbusch, M. \& Brummer, G.-J.A. 1995. A sediment trap investigation of sinking coccolithophorids in the North Atlantic. Deep-Sea Research I, 42: 1083-1109.

Kroenke, L.W., Berger, W.H., Janecek, T.R. et al. (Eds). 1991. Proceedings of Ocean Drilling Program, Initial Reports, 130: 1-556. College Station, TX.

Lyle, M., Dadey, K.A. \& Farrell, J.W. 1995. The late Miocene (11-8 Ma) eastern Pacific carbonate crash: evidence for reorganisation of deep water circulation by the closure of the Panama gateway. Proceedings of the Ocean Drilling Program, Scientific Results, 138: 821-838.

McCave, I.N., Manighetti, B. \& Robinson, S.G. 1995. Sortable silt and fine sediment size-composition slicing: parameters for palaeocurrent speed and palaeoceanography. Paleoceanography, 10: 593-610.

Minoletti, F., Gardin, S., Nicot, E., Renard, M. \& Spezzaferri, S. 2001. Mise au point d'un protocole experimental de separation granulometrique d'assemblages de nannofossiles calcaires; applications paleoecologiques et geochimiques. Bulletin de la Société Géologique de France, 172: 437-446.

Perch-Nielsen, K. 1985. Cenozoic calcareous nannofossils. In Bolli, H.M., Saunders, J.B. \& Perch-Nielsen, K. (Eds), Plankton Stratigraphy. Cambridge University Press, Cambridge, 427-554.

Raffi, I. \& Flores, J.-A. 1995. Pleistocene through Miocene calcareous nannofossils from eastern equatorial Pacific Ocean (Leg 138). In Pisias, N.G., Mayer, L.A., Janecek, T.R., Palmer-Julson, A. \& Andel, T.H. van (Eds), Proceedings of the Ocean Drilling Program, Scientific Results, 138: $233-286$.

Ramsay, A.T.S. 1972. Aspects of the distribution of fossil species of calcareous nannoplankton in North Atlantic and Caribbean sediments. Nature, 236: 67-70.

Roth, M.J., Droxler, A.W. \& Kameo, K. 2000. The Caribbean Carbonate Crash at the Middle to Late Miocene Transition: linkage to the establishment of the Modern Global Ocean Conveyor. In Leckie, R.M., Sigurdsson, H., Acton, G.D. \& Draper, G. (Eds), Proceedings of the Ocean Drilling Program, Scientific Results, 165: 249-273.

Samtleben, C. \& Bickert, T. 1990. Coccoliths from the Norwegian Sea. Marine Micropaleontology, 16: 39-64.

Shackleton, N.J. \& Crowhurst, S. 1997. Sediment fluxes based on an orbitally tuned time scale 5 to $14 \mathrm{Ma}$, Site 926. In Shackleton, N.J., Curry, W.B., Richter, C. \& Bralower, T.J. (Eds), Proceedings of the Ocean Drilling Program, Scientific Results, 154: 69-82.

Takayama, T. 1993. Notes on Neogene calcareous nannofossil biostratigraphy of the Ontong Java Plateau and size variations of Reticulofenestra coccoliths. In Berger, W.H., Kroenke, L.W., Mayer, L.A. et al. (Eds), Proceedings of the Ocean Drilling Program, Scientific Results, 130: 179-229.

Young, J.R. \& Ziveri, P. 2000. Calculation of coccolith volume and its use in calibration of carbonate flux estimates. Deep-Sea Research II, 47: $1679-1700$ 